\title{
CASC1 Gene
}

National Cancer Institute

\section{Source}

National Cancer Institute. CASC1 Gene. NCI Thesaurus. Code C112053.

This gene may play a role in the pathogenesis of certain types of cancer. 